\title{
Front Matter: Volume 6442
}

, "Front Matter: Volume 6442," Proc. SPIE 6442, Multiphoton Microscopy in the Biomedical Sciences VII, 644201 (31 March 2007); doi:

10.1117/12.729065

SPIE. Event: SPIE BiOS, 2007, San Jose, California, United States 


\title{
PROGRESS IN BIOMEDICAL OPTICS AND IMAGING
}

Vol. 8, No. 19

\section{Multiphoton Microscopy in the Biomedical Sciences VII}

\author{
Ammasi Periasamy \\ Peter T. C. So \\ Chairs/Editors
}

21-23 January 2007

San Jose, California, USA

Sponsored by

SPIE-The International Society for Optical Engineering

Carl Zeiss Inc. (USA)

Chroma Technology Corporation (USA)

Coherent (USA)

High Q Laser (USA)

Newport-Spectra Physics (USA)

Volume 6442 
The papers included in this volume were part of the technical conference cited on the cover and title page. Papers were selected and subject to review by the editors and conference program committee. Some conference presentations may not be available for publication. The papers published in these proceedings reflect the work and thoughts of the authors and are published herein as submitted. The publisher is not responsible for the validity of the information or for any outcomes resulting from reliance thereon.

Please use the following format to cite material from this book:

Author(s), "Title of Paper," in Multiphoton Microscopy in the Biomedical Sciences VII, edited by Ammasi Periasamy, Peter T. C. So, Proceedings of SPIE Vol. 6442 (SPIE, Bellingham, WA, 2007) Article CID Number.

ISSN 1605-7422

ISBN 9780819465559

Published by

SPIE-The International Society for Optical Engineering

P.O. Box 10, Bellingham, Washington 98227-0010 USA

Telephone 1 360/676-3290 (Pacific Time) · Fax 1 360/647-1445

http://www.spie.org

Copyright (C) 2007, The Society of Photo-Optical Instrumentation Engineers

Copying of material in this book for internal or personal use, or for the internal or personal use of specific clients, beyond the fair use provisions granted by the U.S. Copyright Law is authorized by SPIE subject to payment of copying fees. The Transactional Reporting Service base fee for this volume is $\$ 18.00$ per article (or portion thereof), which should be paid directly to the Copyright Clearance Center (CCC), 222 Rosewood Drive, Danvers, MA 01923. Payment may also be made electronically through CCC Online at http://www.copyright.com. Other copying for republication, resale, advertising or promotion, or any form of systematic or multiple reproduction of any material in this book is prohibited except with permission in writing from the publisher. The CCC fee code is $1605-$ 7422/07/\$18.00.

Printed in the United States of America. 


\section{Contents}

ix Conference Committee

\section{CARS AND RAMAN MICROSCOPY I}

644205 Single pulse interferometric coherent anti-Stokes Raman scattering (CARS) [6442-04] S.-H. Lim, A. G. Caster, S. R. Leone, Univ. of California, Berkeley (USA) and Lawrence Berkeley National Lab. (USA)

644206 Quantitative multiplex CARS spectroscopy in congested spectral regions (Invited Paper) [6442-05]

M. Müller, H. A. Rinia, Univ. of Amsterdam (Netherlands); M. Bonn, FOM Institute for Atomic and Molecular Physics (Netherlands); E. M. Vartiainen, Lappeenranta Univ. of Technology (Finland); M. Lisker, A. van Bel, Institut für Allgemeine Botanik und Pflanzenphysiologie (Germany)

644208 Coherent anti-Stokes Raman scattering microscope with a high-signal-to-noise ratio, high stability, and high-speed imaging for live cell observation [6442-07]

S. Hayashi, S. Takimoto, T. Hashimoto, Olympus Corp. (Japan)

644209 Raman versus CARS microscopy: when one is better than the other [6442-08]

G. I. Petrov, R. Arora, A. Saha, R. D. Heathcote, Univ. of Wisconsin, Milwaukee (USA); S. Ravula, I. Brener, Sandia National Labs. (USA); V. V. Yakovlev, Univ. of Wisconsin, Milwaukee (USA)

\section{CARS AND RAMAN MICROSCOPY II}

64420C CARS imaging with a new 532-nm synchronously pumped picosecond OPO [6442-11] E. Büttner, APE GmbH (Germany); S. Carrasco, C. L. Evans, F. S. Ganikhanov, Harvard Univ. (USA); J. G. Herbst, APE GmbH (Germany); D. Kopf, HighQ Laser Production GmbH (Austria); I. Rimke, APE GmbH (Germany); S. Xie, Harvard Univ. (USA)

Pagination: Proceedings of SPIE follow an e-First publication model, with papers published first online and then in print and on CD-ROM. Papers are published as they are submitted and meet publication criteria. A unique, consistent, permanent citation identifier (CID) number is assigned to each article at the time of the first publication. Utilization of CIDs allows articles to be fully citable as soon they are published online, and connects the same identifier to all online, print, and electronic versions of the publication.

SPIE uses a six-digit CID article numbering system in which:

- The first four digits correspond to the SPIE volume number.

- The last two digits indicate publication order within the volume using a Base 36 numbering system employing both numerals and letters. These two-number sets start with 00, 01, 02, 03, 04, 05, 06, 07, 08, 09, 0A, OB ... 0Z, followed by 10-1Z, 20-2Z, etc.

The CID number appears on each page of the manuscript. The complete citation is used on the first page, and an abbreviated version on subsequent pages. 
64420D Non-scanning CARS microscopy using wide-field geometry [6442-12] I. Toytman, K. Cohn, T. Smith, D. Simanovskii, Stanford Univ. (USA); D. Palanker, Stanford Univ. (USA) and Stanford Univ. School of Medicine (USA)

64420E Epi-detected coherent anti-Stokes Raman scattering imaging of deep tissues in vivo [6442-13]

T. B. Huff, Purdue Univ. (USA); J.-X. Cheng, Purdue Univ. (USA) and Weldon School of Biomedical Engineering, Purdue Univ. (USA)

$64420 \mathrm{D}$ Dual-CARS microscopy (Invited Paper) [6442-15]

A. Enejder, C. Brackmann, O. Burkacky, M. Åkeson, Chalmers Univ. of Technology (Sweden)

64420I Interferometric Fourier transform coherent anti-Stokes Raman microscopy [6442-17]

M. Cui, J. Skodack, J. P. Ogilvie, Univ. of Michigan (USA)

\section{TECHNOLOGY DEVELOPMENT AND APPLICATIONS I}

64420M Combined spectrally resolved multiphoton microscopy and transmission microscopy employing a high-sensitivity electron-multiplying CCD camera [6442-21]

V. Raicu, R. Fung, M. Melnichuk, A. Chaturvedi, D. Gillman, Univ. of Wisconsin, Milwaukee (USA)

644200 Infrared multiphoton microscopy beyond 1 micron: system design and biomedical applications [6442-23]

I. Rimke, E. Büttner, APE GmbH (Germany); V. Andresen, LaVision BioTec GmbH (Germany);

P. Friedl, Univ. of Würzburg (Germany)

64420P Undistorted delivery of sub-15-fs pulses via high-numerical-aperture microscope objectives [6442-24]

G. Tempea, FEMTOLASERS Produktions GmbH (Austria); B. Považay, Cardiff Univ. (United Kingdom) and Institute of Medical Physics (Austria); A. Assion, A. Isemann, FEMTOLASERS Produktions GmbH (Austria); W. Pervak, Max-Planck-Institut für Quantenoptik (Germany); M. Kempe, Carl Zeiss Jena GmbH (Germany); A. Stingl, FEMTOLASERS Produktions GmbH (Austria); W. Drexler, Cardiff Univ. (United Kingdom) and Institute of Medical Physics (Austria)

64420Q Fiber coupling of an infrared femtosecond laser to a multiphoton microscope [6442-25] A. Courjaud, E. Mottay, Amplitude Systèmes (France); P. Legros, D. Choquet, Univ. Bordeaux 2 (France)

64420R Comparative study of two-photon fluorescent bio-markers at nanosecond and femtosecond pulsed excitation [6442-26]

B. H. Peterson, Alabama A\&M Univ. (USA); S. S. Sarkisov, SSS Optical Technologies, LLC (USA); V. N. Nesterov, New Mexico Highlands Univ. (USA); M. J. Curley, Alabama A\&M Univ. (USA); A. Urbas, Air Force Research Lab. (USA); D. N. Patel, Oakwood College (USA);

J.-C. Wang, Alabama A\&M Univ. (USA)

64420T Adaptive optics in confocal and two-photon microscopy of rat brain: a single correction per optical section [6442-28]

J. M. Girkin, J. Vijverberg, M. Orazio, S. Poland, A. J. Wright, Univ. of Strathclyde (United Kingdom) 
64420 Multidimensional fluorescence lifetime measurements [6442-30]

C. Biskup, B. Hoffmann, Friedrich-Schiller-Univ. Jena (Germany); L. Kelbauskas, FriedrichSchiller-Univ. Jena (Germany) and Biodesign Institute, Arizona State Univ. (USA); T. Zimmer, S. Dietrich, Friedrich-Schiller-Univ. Jena (Germany); W. Becker, A. Bergmann, Becker \& Hickl GmbH (Germany); N. Klöcker, Albert-Ludwigs-Univ. Freiburg (Germany); K. Benndorf, Friedrich-Schiller-Univ. Jena (Germany)

64420W Refractive index sensing using fluorescence lifetime imaging (FLIM) [6442-31]

C. Tregidgo, K. Suhling, King's College London (United Kingdom)

64420Y SLIM: A sophisticated method for molecular imaging (Invited Paper) [6442-33]

A. Rück, F. Dolp, R. Steiner, Institute for Laser Technologies in Medicine and Metrology

(Germany); S. Lintner, B. v. Einem, C. v. Arnim, Univ. Ulm (Germany)

$64420 Z$ Fluorescent peptides to investigate amyloid self-assembly using two-photon microscopy [6442-34]

Y. Liang, D. G. Lynn, K. Berland, Emory Univ. (USA)

\section{SECOND-HARMONIC GENERATION MICROSCOPY}

644215 Clinical in vivo two-photon microendoscopy for intradermal high-resolution imaging with GRIN optics (Invited Paper) [6442-40]

K. König, A. Ehlers, Fraunhofer Institute of Biomedical Technology (Germany) and Saarland Univ. (Germany); I. Riemann, Fraunhofer Institute of Biomedical Technology (Germany); S. Schenkl, Saarland Univ. (Germany); B. Messerschmidt, GrinTech GmbH (Germany); R. Bückle, R. Le Harzic, JenLab GmbH (Germany); P. Elsner, M. Kaatz, Univ. Jena (Germany)

644219 Study of skeletal muscle cross-bridge population dynamics by second harmonic generation [6442-44]

V. Nucciotti, C. Stringari, L. Sacconi, F. Vanzi, C. Tesi, N. Pirrodi, C. Poggesi, Univ. of Florence (Italy); C. Castiglioni, A. Milani, Politecnico Milano (Italy); M. Linari, G. Piazzesi, V. Lombardi, F. S. Pavone, Univ. of Florence (Italy)

$64421 \mathrm{~A}$ Third harmonic generation: anomalous behavior in the THG z-response and microscopy applications [6442-45]

R. S. Pillai, G. J. Brakenhoff, M. Müller, Univ. of Amsterdam (Netherlands)

64421B Spectrally resolved multiphoton imaging of post-mortem biopsy and in vivo mouse skin tissues (Invited Paper) [6442-46]

J. A. Palero, Utrecht Univ. (Netherlands); H. S. de Bruijn, A. van der Ploeg van den Heuvel, H. J. C. M. Sterenborg, Erasmus Medical Ctr., Rotterdam (Netherlands); H. C. Gerritsen, Utrecht Univ. (Netherlands)

$64421 \mathrm{C}$ Second-harmonic generation polarization microscopy by rotation of excitation light [6442-47]

P. T. Fwu, C.-K. Chou, W.-L. Chen, C.-Y. Dong, National Taiwan Univ. (Taiwan) 
64421D Second-harmonic generation investigation of collagen thermal denaturation [6442-48] W.-L. Chen, Y. Sun, National Taiwan Univ. (Taiwan); S.-J. Lin, National Taiwan Univ. Hospital and College of Medicine (Taiwan) and Institute of Biomedical Engineering, National Taiwan Univ. (Taiwan); S.-H. Jee, National Taiwan Univ. Hospital and College of Medicine (Taiwan); Y.-F. Chen, L.-C. Lin, National Taiwan Univ. (Taiwan); P. T. C. So, Massachusetts Institute of Technology (USA); C.-Y. Dong, National Taiwan Univ. (Taiwan)

\section{TECHNOLOGY DEVELOPMENT AND APPLICATIONS II}

$64421 \mathrm{~F}$ Optical nano-injection into cells and 3D stem cell clusters via a NIR femtosecond laser [6442-50]

I. Riemann, F. Stracke, A. Uchugonova, Fraunhofer Institute of Biomedical Technology (Germany); S. Martin, R. Bückle, JenLab GmbH (Germany); K. König, Fraunhofer Institute of Biomedical Technology (Germany)

$64421 \mathrm{G}$ Two-photon fluorescence background rejection by differential aberration imaging [6442-51]

A. Leray, K. Lillis, J. Mertz, Boston Univ. (USA)

644211 Time-resolved multiphoton imaging of basal cell carcinoma [6442-53]

R. Cicchi, S. Sestini, V. De Giorgi, D. Stambouli, P. Carli, D. Massi, F. S. Pavone, Univ. of Florence (Italy)

$64421 \mathrm{~J}$ Self-phase modulation and two-photon absorption imaging of cells and active neurons [6442-54]

M. C. Fischer, Duke Univ. (USA); H. Liu, Princeton Univ. (USA); I. R. Piletic, T. Ye, Duke Univ. (USA); R. Yasuda, Duke Univ. Medical Ctr. (USA); W. S. Warren, Duke Univ. (USA)

64421L Two-photon characterization and microscopy of porphyrin photosensitisers [6442-56] S. Mathai, D. K. Bird, Univ. of Melbourne (Australia); S. S. Stylli, Royal Melbourne Hosptital (Australia); T. A. Smith, K. P. Ghiggino, Univ. of Melbourne (Australia)

$64421 \mathrm{M}$ Two-photon deep imaging through skin and skull of zebra finches: preliminary studies for in-vivo brain metabolism monitoring [6442-57]

D. Abi-Haidar, T. Olivier, S. Mottin, CNRS, Univ. of Saint-Étienne (France); C. Vignal,

N. Mathevon, Univ. of Saint-Étienne (France)

644210 Laser-induced microlesion of single dendrites in living mice [6442-59]

L. Sacconi, Univ. of Florence (Italy); R. Panteri, Univ. Campus Bio-Medico (Italy); A. Masi, Univ. of Florence (Italy); G. Diana, Istituto Superiore di Sanità (Italy); M. Buffelli, Univ. of Verona (Italy); F. Keller, Univ. Campus Bio-Medico (Italy); F. S. Pavone, Univ. of Florence (Italy)

\section{POSTER SESSION}

64421P Multiphoton fluorescence imaging of NADH to quantify metabolic changes in epileptic tissue in vitro [6442-60]

T. H. Chia, J. Zinter, D. D. Spencer, A. Williamson, M. J. Levene, Yale Univ. (USA) 
$64421 \mathrm{Q}$ Interleaved dual-wavelength multiphoton imaging system for heterologous FRET and versatile fluorescent protein excitation [6442-61]

M. A. Zal, M. Nelson, T. Zal, Univ. of Texas M.D. Anderson Cancer Ctr. (USA)

64421R Intravital multiphoton microscopy for imaging hepatobiliary function [6442-62]

W. Lo, Y. Liu, National Taiwan Univ. (Taiwan); H.-C. Chen, S.-M. Yang, National Taiwan Univ. Hospital (Taiwan) and National Taiwan Univ. (Taiwan); T.-L. Sun, National Taiwan Univ. (Taiwan); L.-L. Chiou, G.-T. Huang, National Taiwan Univ. Hospital (Taiwan) and National Taiwan Univ. (Taiwan); C.-Y. Dong, National Taiwan Univ. (Taiwan); H.-S. Lee, National Taiwan Univ. Hospital (Taiwan) and National Taiwan Univ. (Taiwan)

644215 Backward second-harmonic generation from starch for in situ real time pulse characterization in multiphoton microscopy [6442-63]

A. Thayil K. N., E. J. Gualda, I. G. Cormack, Institut de Ciències Fotòniques (Spain); S. Soria, Institut de Ciències Fotòniques (Spain) and Ctr. Studi e Ricerche Enrico Fermi (Italy);

P. Loza-Alvarez, Institut de Ciències Fotòniques (Spain)

$64421 \mathrm{~T}$ Second-harmonic and two-photon imaging and polarimetry of articular cartilage [6442-64] J. Mansfield, C. P. Winlove, J. Moger, K. Knapp, Univ. of Exeter (United Kingdom);

S. Matcher, Univ. of Sheffield (United Kingdom)

$64421 \mathrm{U}$ Myosin rods are a source of second harmonic generation signals in skeletal muscle [6442-65]

S. Schürmann, C. Weber, R. H. A. Fink, Univ. Heidelberg (Germany); M. Vogel, Univ. Heidelberg (Germany) and Harvard Univ. (USA)

64421Y In vivo multiphoton endoscopy of endogenous skin fluorophores [6442-69]

A. Ehlers, S. Schenkl, Fraunhofer-Institut for Biomedical Technology (Germany) and Saarland Univ. (Germany); I. Riemann, Fraunhofer-Institut for Biomedical Technology (Germany); B. Messerschmidt, GrinTech GmbH (Germany); M. Kaatz, Friedrich Schiller Univ. (Germany); R. Bückle, JenLab GmbH (Germany); K. König, Fraunhofer-Institut for Biomedical Technology (Germany), Saarland Univ. (Germany), and JenLab GmbH (Germany)

$64421 Z$ The influence of NIR femtosecond laser radiation on the viability of 3D stem cell clusters and tumor spheroids [6442-70]

A. Uchugonova, I. Riemann, F. Stracke, E. Gorjup, Fraunhofer Institute of Biomedical Technology (Germany); R. LeHarzic, JenLab GmbH (Germany); K. König, Fraunhofer Institute of Biomedical Technology (Germany)

644220 In vivo mucosal tissue imaging using fiber-based two-photon approach [6442-71] X. Xiao, S. Tuya, G. Vargas, The Univ. of Texas Medical Branch at Galveston (USA)

644221 Optical effects of the cranium in trans-cranial in vivo two photon laser scanning microscopy in mice [6442-72]

P. J. Helm, O. P. Ottersen, G. Nase, Ctr. for Molecular Biology and Neuroscience, Univ. of Oslo (Norway)

644223 Acceptor spectral bleedthrough correction in spectral FRET imaging microscopy [6442-74] Y. Chen, A. Periasamy, Univ. of Virginia (USA) 
644224 SIPcharts using uniform ultra-thin and thin layers for z-response measurements in two-photon excitation fluorescence microscopy [6442-75]

G. Vicidomini, Univ. of Genoa (Italy) and IFOM (Italy); J. M. Zwier, Univ. of Amsterdam (Netherlands); P. Bianchini, Univ. of Genoa (Italy) and IFOM (Italy); F. Cella, Univ. of Genoa (Italy); E. Ronzitti, Univ. of Genoa (Italy) and IFOM (Italy); S. Krol, Univ. of Genoa (Italy); T. Szellas, Leica Microsystems CMS (Germany); G. F. Brakenhoff, Univ. of Amsterdam (Netherlands); A. Diaspro, Univ. of Genoa (Italy), CNR Institute of Biophysics (Italy), and IFOM (Italy)

644225 FT-Raman spectra of platymonas subcordiformis [6442-77]

R. Chen, Y. Li, L. Wang, L. Ou, H. Lin, L. Xie, H. Zhuang, Fujian Normal Univ. (China)

644226 In vivo multiphoton tomography of skin during wound healing and scar formation [6442-78] I. Riemann, A. Ehlers, Fraunhofer Institute of Biomedical Technology (Germany); R. LeHarzic, S. Martin, JenLab GmbH (Germany); A. Reif, Univ. Jena (Germany); K. König, Fraunhofer Institute of Biomedical Technology (Germany)

644227 Multiphoton and magnetic resonance imaging of barley embryos: comparing microimaging techniques across scale and parameter barriers [6442-79]

M. Stark, B. Manz, I. Riemann, F. Volke, Fraunhofer Institute of Biomedical Technology (Germany); W. Weschke, Institut für Pflanzengenetik und Kulturpflanzenforschung (Germany); K. König, Fraunhofer Institute of Biomedical Technology (Germany)

644228 EosFP: a multi-state photoconvertible protein from the coral Lobophyllia hemprichii [6442-81]

A. Salih, Univ. of Sydney (Australia); J. Wiedmann, Univ. of Ulm (Germany); G. Cox, Univ. of Sydney (Australia)

Author Index 


\title{
Conference Committee
}

\author{
Symposium Chairs
}

James G. Fujimoto, Massachusetts Institute of Technology (USA)

R. Rox Anderson, Wellman Center for Photomedicine, Massachusetts

General Hospital, and Harvard School of Medicine (USA)

Program Track Chairs

Ammasi Periasamy, University of Virginia (USA)

Daniel L. Farkas, Cedars-Sinai Medical Center (USA)

Conference Chairs

Ammasi Periasamy, University of Virginia (USA)

Peter T. C. So, Massachusetts Institute of Technology (USA)

Program Committee

Guy C. Cox, University of Sydney (Australia)

Alberto Diaspro, University of Genoa (Italy)

Scott E. Fraser, California Institute of Technology (USA)

Hans C. Gerritsen, Utrecht University (Netherlands)

Min Gu, Swinburne University of Technology (Australia)

Stefan W. Hell, Deutsches Krebsforschungszentrum (Germany)

Brian A. Herman, The University of Texas Health Science Center at San Antonio (USA)

Satoshi Kawata, Osaka University (Japan)

Karsten König, Fraunhofer Institute of Biomedical Technology (Germany)

Arnd K. Krueger, Spectra-Physics Lasers (USA)

Joseph R. Lakowicz, University of Maryland/Baltimore (USA)

Stephen M. McDonald, Coherent, Inc. (USA)

Jerome Mertz, Boston University (USA)

Simon C. Watkins, University of Pittsburgh (USA)

Paul W. Wiseman, McGill University (Canada)

David L. Wokosin, Northwestern University (USA)

Sunney S. Xie, Harvard University (USA)

Bernhard Zimmermann, Carl Zeiss Jena GmbH (Germany)

Warren R. Zipfel, Cornell University (USA)

Session Chairs

CARS and Raman Microscopy I

Sunney S. Xie, Harvard University (USA) 
CARS and Raman Microscopy II

Michiel Mueller, Universiteit van Amsterdam (Netherlands)

Technology Development and Applications I

Peter T. C. So, Massachusetts Institute of Technology (USA)

FRET, FLIM, and FCS

Keith M. Berland, Emory University (USA)

Karsten König, Fraunhofer Institute of Biomedical Technology (Germany)

Second-Harmonic Generation Microscopy

Paul J. Campagnola, University of Connecticut Health Center (USA)

Chen-Yuan Dong, National Taiwan University (Taiwan)

Technology Development and Applications II

Damian K. Bird, University of Melbourne (Australia)

Poster Session

Keith M. Berland, Emory University (USA)

Angelika C. Rueck, University Ulm (Germany)

Paul J. Campagnola, University of Connecticut Health Center (USA) 